\title{
COMPARISON OF INTEGRATED MANAGEMENT OF NEONATAL AND CHILDHOOD ILLNESS (IMNCI) ACTIVITIES AMONGST FRONTLINE WORKERS OF HEALTH AND ICDS SECTORS IN DIBRUGARH DISTRICT OF ASSAM AND EFFECT OF MONITORING AND SUPERVISION - A PROCESS EVALUATION
}

Dr Tulika Goswami Mahanta, Dr Ajay Trakroo, Mr Pranab Gogoi, Dr Pranabjyoti Bhuyan, Dr Nabanita Nirmolia, Dr Ranjan Baruah

1. Associate Professor, Department of Community Medicine, Assam Medical College, Dibrugarh

2. Health Specialist, UNICEF

3. Research Assistant cum Statistician

4. Assistant Director, NCDC, Coonoor Branch

5. Assistant Professor, Department of Community Medicine, Assam Medical College, Dibrugarh

6. Medical \& Health Officer

\section{CORRESPONDING AUTHOR:}

Dr Tulika Goswami Mahanta,

House No-16, Ward -19,

Satsang Vihar Road,

Jyotinagar, Dibrugarh.

Email-drtulikagoswami@gmail.com

ABSTRACT: Background-IMNCI offers a strategy for improving the state of health of children in India. This approach could help the country in achieving the MDG Goals of reducing the under-five mortality. Objectives- To assess and compare the knowledge and skills of IMNCI service providers at peripheral level and effect of monitoring and supervision. Methods- A baseline cross sectional study to compare the activity of frontline workers of both health and ICDS sector and then follow up to assess the effect of monitoring and supervision in a subgroup. Results and Conclusion- IMNCI is found effective in improving knowledge, skill, accuracy in assessment, classification, treatment and counselling amongst both health and ICDS sector. Assessment by ANM and AWW for bacterial infection shows highly significant difference in 0-2 month, assessment of immunization and other problems also showing significant difference, but no significant difference is found in assessment of diarrhoea and breast feeding $(\mathrm{p}<0.05$.$) . Monitoring and supervision; showing significant improvement in$ implementation of IMNCI in the district ( $\mathrm{p}<0.05$.). Keywords- IMNCI, Dibrugarh, ICDS, AWW, ANM, Frontline worker, Monitoring and supervision

\section{INTRODUCTION:}

Annually, over 10 million children in low- and middle-income countries die from preventable or treatable illnesses such as diarrheal dehydration, ARI, measles, malaria, and malnutrition. ${ }^{1}$ India committed to achieve the MDG Goal \#4 aims to reduce under-5 mortality by two-thirds between 1990 and $2015^{2}$. Due to high neonatal mortality and morbidity in the country, GOI revised the strategy to be called IMNCI to addresses various aspects of nutrition, immunization and other important elements of disease prevention and health promotion ${ }^{3}$. 
Poor living conditions like lack of safe water supply, poor hygiene, overcrowding; inability of parents to recognize danger signs; and delay in seeking appropriate treatment is compounded by the poor quality of care provided at health facilities. ${ }^{4}$ Projections based on 1996 analysis in the Global Burden of Disease indicate that these conditions will continue to make major contributions to childhood mortality through the year 2020 unless significant greater efforts are made to control them. ${ }^{5}$ Therefore this study was conducted to assess and compare the knowledge and skills of health and ICDS workers.

\section{MATERIALS AND METHODS:}

Dibrugarh district, is spread over $3381 \mathrm{sq} \mathrm{km}$ area, and is populated by about 1.2 million individuals (0.9 million rural, 0.3 million urban). In the rural areas, unit of healthcare delivery is sub centre and 1362 villages are distributed in 231 sub centres (One sub centre has about five villages. In the total of 231 rural sub centres 438 ANMs were posted and 1632 AWWs from ICDS sector were serving as IMNCI service provider. This implementation research was undertaken for a period of one year i.e., from October 2010 to Sept'2011. Following indicators were used: 1. Performance indicator of Service Providers (ANM/AWW) like- \% Monthly reporting coverage, Accuracy of assessment/classification/treatment, \% of Home-visits of newborn, Referral etc. 2. Logistic \& supply- Availability of weighing machine, drugs, forms etc. 3. Random cross-checking of home-visit. 4. Knowledge, attitude and practice of Child care amongst service provider and beneficiary. All IMNCI frontline service providers were visited by the study investigators and a second visit was imparted for reassessment and to assess the improvement in at least $20 \%$ of the service providers. Pretested, predesigned questionnaire along with a format for qualitative assessment by observation method were used to assess the performance of frontline service providers. IMNCI record review and on site skill assessment was done by case observation to see the accuracy in assessment, classification and treatment. All monthly meetings were attended by study investigators (Facilitators) and all recording and reporting forms were analysed in each Block PHC meetings and service providers were encouraged and motivated to carry out their activity more efficiently. Quarterly report of data collected and analysed was compared and analysed in rates and ratios. Univariate data analysis done by chi square test. The $\mathrm{p}$ value $<0.05$ was considered significant. IMNCI reporting data were also analysed. Data analysis was done using SPSS 17 package.

Post natal mothers were checked for feeding problems such as feeding less than eight times in the last $24 \mathrm{~h}$, giving any other food or drinks and low weight for age. Information regarding lactating mothers' skills for proper positioning and attachment of infant while breastfeeding is lacking. Hence, the present study includes the assessmentof breastfeeding skills and practices among the mothers of below six months children.

Baby's weight was taken and plotted on the growth chart provided on the IMNCI booklet to assess low weight for age. If the infant was not fed in the previous hour, the mother was asked to put her infant to the breast. If the infant was fed during the last one hour, then the mother was asked when the infant would feed again and the assessment was planned accordingly. Auxiliary Nurse Midwives observed the breastfeeding process for four minutes and recorded the infant's positioning and attachment to the breast as per IMNCI guidelines. A infant was said to have poor attachment when there was chin not touching the breast, mouth not wide open, lower lip not turned outward or little areola visible above than below the mouth. The poor positioning of the infant was recognized by signs like infant's neck was twisted or bent forward, infant's body was turned away from mother, infant's body not close to mother or only infants' 
neck and head were supported. After recording the observations, if there was difficulty with positioning or attachment, the mother was helped to position and attach her infant better. The whole process of assessment, classification and counselling by IMNCI service provider was assessed observed by study investigator.

\section{RESULTS:}

There are six bock primary health centres in the District covering the whole rural population i.e., $85 \%$. Table 1 shows the number of visits to IMNCI service providers by study team.

A total of 2093 workers were trained in by IMNCI training. Of which, 1959 (94\%) were visited in first assessment visit and 892 (43\%) got the second assessment visit. (Table 1)

All service providers were trained within last three year with majority having a gap from training to assessment of 12 to 24 months.

\section{Opinion of IMNCI service providers regarding difference in their work after training (Table-2)}

Regarding change in knowledge level - $61 \%$ informed that they had knowledge gain in areas of newborn and child care, while $36.14 \%$ informed that there is increase in knowledge in some areas of newborn and child care and 2.86 narrated that they had no change in knowledge level after IMNCI training.

While asked about improvement in skill level 61.05\% informed about improvement in all areas, while $35.94 \%$ had improvement in some areas and $3.01 \%$ had no improvement as per their opinion.

$60.95 \%$ developed confidence in all areas of newborn and child care, 35.48\% were confident in some areas of newborn and child health care and $3.57 \%$ were still not gaining any confidence in giving newborn and child health care.

$59.72 \%$ informed that their credibility in community in increasing in all areas of newborn and child care, while $36.29 \%$ says that there is increase in some areas and $3.98 \%$ says that there is no alteration.

$63.14 \%$ described as increase in workload in all areas and $13.48 \%$ informed as increase in some activities, while $23.38 \%$ described as no change in work load.(Table 2)

\section{Comparison between assessment done by ANM and AWW (0-2 months)}

Assessment by ANM and AWW for bacterial infection shows highly significant difference in 0-2 month, while assessment of immunization and other problems also showing significant difference, but no significant difference is found between assessment of diarrhoea and breast feeding.(Table -3)

\section{2month to 5years child case assessment:}

In field assessment and classification of 2 months to 5 years age group comparison between ANM and AWW shows statistically significant difference in general danger sign assessment, malnutrition and anaemia assessment and assessment of other problems. While there is no significant difference assessment of cough/ difficult breathing, diarrhoea and fever amongst ANM and AWW (Table-3) 
Comparison between first assessment visit and second assessment visit for 0-2 months by study investigator i.e., IMNCI facilitators shows statistically significant result in assessment of possible serious bacterial infection, diarrhoea, immunization and elicitation of other problem; while no significant difference found in feeding assessment amongst 0-2 months age group(Table-4).

2month to 5years child case assessment : Comparison between first and second visit shows significant difference in elicitation of general danger sign, diarrhoea, malnutrition, anaemia and other problem; while there is no significant change in assessment of cough/difficult breathing and fever ( Table 4).

Comparison of each quarter monitoring and supervision report with statistical analysis: Quarter wise comparison of monitoring and supervision shows statistically significant difference in most of the quarters. (Table -5)

Consecutive quarter wise comparison from Jan to Sept'2010 shows significant improvement home visit by IMNCI service providers $(\mathrm{p}<0.05$.) (Table 5)

Consecutive comparison of 3 Post natal visit within 10 days by IMNCI service providers shows significant in each quarter $(\mathrm{p}<0.05)($ Table -5$)$

\section{DISCUSSION:}

The programme was implemented as per plan of action. Our study shows high accuracy in assessment and classification of infant and children. Especially in feeding assessment both ANM and AWW are doing the assessment correctly in majority of cases. The major strength of IMNCI strategy is that it makes use of evidence-based management decisions like oral rehydration therapy for diarrhoea, childhood vaccinations to reduce deaths due to diphtheria, pertussis, and measles and antibiotic treatment for pneumonia. Other strong points of IMNCI are the hands-on clinical training for $50 \%$ of training time, feasibility of its incorporation into pre-service education and in service training, focus on communication and counselling skills, and locally adapted recommendation for infant and young child feeding. By improving the coordination and quality of services provided by existing child health and other programmes, the IMNCI strategy will increase the effectiveness of care and simultaneously reduce the cost. IMNCI has the potential of lowering the burden on hospitals, particularly, in urban areas where access to care is not a limiting factor. It offers a model for improving one aspect of service delivery that could be applied to other aspects of health care. On the other hand, a critical appraisal of IMNCI revealed that it has failed to address the key issues of safe home delivery, training of traditional birth attendants, creating facilities for a triage system at primary, secondary, and tertiary care levels, a referral system with linkages between these levels, care of newborn at birth and childhood injuries. ${ }^{6}$

The recently developed child growth standards of World Health Organization (WHO) standards, $39 \%$ of the children below six months of age are underweight. ${ }^{7}$ This finding indicated feeding problems in children below six months of age. In 2003, the WHO recommended infants be fed exclusively on breast milk until six months of age. ${ }^{8}$ Breastfeeding provides significant health benefits for infants and mothers. It has also been found to protect against delays in young children's language and motor skill development. ${ }^{9}$ Thus, there is a need for promotion and protection of optimal infant feeding practices for improving nutritional status of children. The 
IMNCI strategy recommended systematic assessment of breastfeeding and emphasized counselling of the mother on proper positioning and attachment of infant to the breast. ${ }^{10}$

From our study, it was evident that monitoring and supervision clearly showing improvement in implementation of IMNCI in the district. There is evidence from data collected and comparison between quarters that there is continuous improvement in IMNCI implementation in the District; which may be the result of quality monitoring and supportive supervision by facilitators who were also trained in supportive supervision by separate modular training for three days. But continuous supply and replenishment of drugs and other logistics like weighing machine, recording book and new growth chart is essential for sustainability. Inter-sectoral coordination between health and ICDS is another neglected area in both State and District level which needs urgent attention. Average training quality score in the District was 94\%, indicating high quality of training. From the implementation report it was evident that the home visit of babies within 24 hours was $74.1 \%$ in last quarter of which $66.6 \%$ babies got 3 postnatal home visits after delivery, showing continuous improvement than previous quarters. Though sick young infant and sick child referral rate is still low i.e., $7.4 \%$ which requires attention and improvement

\section{REFERENCES:}

1. WHO Department of Child and Adolescent Health and Development (CAH), MOHFW. Student's handbook for Integrated management of neonatal and childhood illness. 2003.

2. Naveen Thacker; President page; Indian Paediatrics 2007; 44: 169-171; Integrated management of neonatal and childhood illnesses: A new hope for child survival.

3. WHO, UNICEF. Module 1 - Introduction. Integrated Management of Neonatal and Childhood Ilnesses . Ministry of health and Family Welfare: India; 2003.

4. WHO. Improving Child health, the integrated approach. Division of Child Health and Development; WHO/CHD/97.12 Rev.2. WHO: 1997. p. 2-7.

5. Murray CJ, Lopez AD. The global burden of disease: A comprehensive assessment of mortality and disability from diseases injures and risk factors in 1990 and projected to

2020. WHO: Geneva; 1996.

6. IAP Action Plan 2006. Available from: http://www.iapindia.org/president.cfm. [Last accessed on 2006 Jun 3].

7. Deshmukh PR, Dongre AR, Gupta SS, Garg BS. Implications of newly developed growth standards. Indian J Pediatr 2007;74:17-20.

8. Britton C, McCormick FM, Renfrew MJ, Wade A, King SE. Support for breastfeeding mothers. Cochrane Database Syst Rev 2007;1:CD001141.

9. Dee DL, Li R, Lee LC, Grummer-Strawn LM. Association between breastfeeding practices and young children's language and motor skill development. Pediatrics 2007;119:592-8.

10. Advantages of breastfeeding. Available from: http://www.breastfeeding.com/all_about/all_about_more2.html. [Last cited on 2009 Nov 7]. 
Table -1: Number of visits to IMNCI service providers by study team

\begin{tabular}{|l|l|l|l|l|}
\hline Type of workers & First visit & Second visit & Total visit made & Total workers \\
\hline AWW & $1531(94 \%)$ & $620(38 \%)$ & 2151 & $1632(100 \%)$ \\
\hline ANM & $409(93 \%)$ & $256(52 \%)$ & 667 & $438(100 \%)$ \\
\hline GNM & $19(83 \%)$ & $16(70 \%)$ & 35 & $23(100 \%)$ \\
\hline Total & $1959(94 \%)$ & $892(43 \%)$ & 2843 & $2093(100 \%)$ \\
\hline
\end{tabular}

Table - 2 - Opinion of IMNCI service providers regarding difference in their work after training

\begin{tabular}{|l|l|l|l|}
\hline & No Change & $\begin{array}{l}\text { Increased to some } \\
\text { areas on NBC and } \\
\text { child care }\end{array}$ & $\begin{array}{l}\text { Increased in all } \\
\text { areas of NBC and } \\
\text { Child care }\end{array}$ \\
\hline Knowledge & 2.86 & 36.14 & 61.00 \\
\hline Skill & 3.01 & 35.94 & 61.05 \\
\hline Confidence among & 3.98 & 35.48 & 60.95 \\
\hline $\begin{array}{l}\text { Credibility } \\
\text { community }\end{array}$ & 3.57 & 36.29 & 59.72 \\
\hline Work Load & 23.38 & 13.48 & 63.14 \\
\hline
\end{tabular}


Table: 3: Performance comparison between ANMs and AWWs as IMNCI service provider in accuracy of assessment and classification

\begin{tabular}{|c|c|c|c|c|c|}
\hline & & $\begin{array}{l}\text { Correct } \\
\text { Classification }\end{array}$ & $\begin{array}{l}\text { Incorrect } \\
\text { Classification }\end{array}$ & Chi-square & p-value \\
\hline \multicolumn{6}{|l|}{0 -2month } \\
\hline \multirow{2}{*}{$\begin{array}{l}\text { Bacterial } \\
\text { Infection }\end{array}$} & ANM & $589(100 \%)$ & $0(0 \%)$ & \multirow[t]{2}{*}{12.546} & \multirow[t]{2}{*}{0.000} \\
\hline & AWW & $1634(97.9 \%)$ & $35(2.1 \%)$ & & \\
\hline \multirow{2}{*}{ Diarrhea } & ANM & 583 (99\%) & $6(1 \%)$ & \multirow{2}{*}{1.319} & \multirow[t]{2}{*}{0.327} \\
\hline & AWW & 1627 (98\%) & $28(1.7 \%)$ & & \\
\hline \multirow{2}{*}{ Breast Feeding } & ANM & $555(98.8 \%)$ & $7(1.2 \%)$ & \multirow[t]{2}{*}{1.278} & \multirow[t]{2}{*}{0.353} \\
\hline & AWW & $1533(98.2 \%)$ & $31(2 \%)$ & & \\
\hline \multirow{2}{*}{ Immunization } & ANM & $561(99.6 \%)$ & $2(.4 \%)$ & \multirow[t]{2}{*}{5.653} & \multirow[t]{2}{*}{0.017} \\
\hline & AWW & $1561(98.3 \%)$ & $27(1.7 \%)$ & & \\
\hline \multirow{2}{*}{ Other Problem } & ANM & 477 (98.4\%) & $8(1.6 \%)$ & \multirow[t]{2}{*}{8.711} & \multirow[t]{2}{*}{0.002} \\
\hline & AWW & $1202(95.3 \%)$ & $59(4.7 \%)$ & & \\
\hline \multicolumn{6}{|c|}{2 months - 5 years } \\
\hline \multirow{2}{*}{$\begin{array}{l}\text { General danger } \\
\text { Signs }\end{array}$} & ANM & $544(97.8 \%)$ & $12(2.2 \%)$ & \multirow[t]{2}{*}{9.820} & \multirow[t]{2}{*}{0.001} \\
\hline & AWW & $1739(94.7 \%)$ & 98 (5.3\%) & & \\
\hline \multirow[t]{2}{*}{$\begin{array}{l}\text { Cough/difficult } \\
\text { breathing }\end{array}$} & ANM & $546(98.7 \%)$ & $7(1.3 \%)$ & \multirow[t]{2}{*}{0.485} & \multirow[t]{2}{*}{0.566} \\
\hline & AWW & $1805(98.3 \%)$ & $31(1.7 \%)$ & & \\
\hline \multirow[t]{2}{*}{ Diarrhea } & ANM & $551(98.2 \%)$ & $10(1.8 \%)$ & \multirow{2}{*}{0.002} & \multirow{2}{*}{1.000} \\
\hline & AWW & $1794(98.2 \%)$ & $32(1.7 \%)$ & & \\
\hline \multirow[t]{2}{*}{ Fever } & ANM & $561(99 \%)$ & $6(1 \%)$ & \multirow[t]{2}{*}{0.003} & \multirow[t]{2}{*}{1.000} \\
\hline & AWW & $1823(99 \%)$ & $19(1 \%)$ & & \\
\hline \multirow[t]{2}{*}{ Malnutrition } & ANM & 537 (96.6\%) & $19(3.4 \%)$ & \multirow[t]{2}{*}{10.143} & \multirow[t]{2}{*}{0.001} \\
\hline & AWW & $1671(92.8 \%)$ & $129(7.2 \%)$ & & \\
\hline \multirow[t]{2}{*}{ Anaemia } & ANM & $523(94.4 \%)$ & $31(5.6 \%)$ & 7.066 & 0.008 \\
\hline & AWW & $1646(90.8 \%)$ & $166(9.2 \%)$ & & \\
\hline Other Problem & ANM & $522(96.8 \%)$ & $17(3.2 \%)$ & 4.581 & 0.030 \\
\hline & AWW & 1655 (94.6\%) & 95 (5.4\%) & & \\
\hline
\end{tabular}




\begin{tabular}{|c|c|c|c|c|c|}
\hline $\begin{array}{l}\text { Table: } 4: \\
\text { provider in accu }\end{array}$ & $\begin{array}{l}\text { formanc } \\
\text { cy of ass }\end{array}$ & $\begin{array}{l}\text { comparison be } \\
\text { sment and clas }\end{array}$ & $\begin{array}{l}\text { n first visit a } \\
\text { tion. }\end{array}$ & second & IMNC \\
\hline $0-2$ month & & & & & \\
\hline & 1st visit & $1145(97.3 \%)$ & $32(2.7 \%)$ & 20517 & 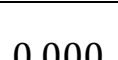 \\
\hline Infection & $\begin{array}{l}\text { 2nd } \\
\text { Visit }\end{array}$ & $1018(99.7 \%)$ & $3(.3 \%)$ & 20.017 & 0.000 \\
\hline & 1 st visit & $1136(97.7 \%)$ & $27(2.3 \%)$ & 9495 & 0003 \\
\hline Diarrhea & $\begin{array}{l}\text { 2nd } \\
\text { Visit }\end{array}$ & $1014(99.3 \%)$ & $7(0.7 \%)$ & 3.493 & 0.005 \\
\hline & 1st visit & $1024(97.6 \%)$ & $25(2.4 \%)$ & 3492 & 207 07 \\
\hline Breast Feeding & $\begin{array}{l}\text { 2nd } \\
\text { Visit }\end{array}$ & $1004(98.7 \%)$ & $13(1.3 \%)$ & 0.492 & 0.072 \\
\hline & 1st visit & $1054(98.0 \%)$ & $21(2.0 \%)$ & 5102 & \\
\hline Immunization & $\begin{array}{l}\text { 2nd } \\
\text { Visit }\end{array}$ & $1008(99.2 \%)$ & $8(0.8 \%)$ & 0.193 & $0.0 \angle 3$ \\
\hline & 1st visit & $780(93.6 \%)$ & $53(6.4 \%)$ & 26231 & 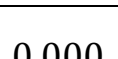 \\
\hline Other Problem & $\begin{array}{l}\text { 2nd } \\
\text { Visit }\end{array}$ & $840(98.5 \%)$ & $13(1.5 \%)$ & 20.231 & 0.000 \\
\hline 2 months -5 yed & & & & & \\
\hline General danger & 1st visit & $1139(92.2 \%)$ & $97(2.0 \%)$ & 56.592 & 0.000 \\
\hline Signs & $\begin{array}{l}\text { 2nd } \\
\text { Visit }\end{array}$ & $1072(98.8 \%)$ & $13(1.2 \%)$ & & \\
\hline Cough/difficult & 1st visit & $1208(98.1 \%)$ & $24(1.9 \%)$ & 1547 & 2520 \\
\hline breathing & $\begin{array}{l}\text { 2nd } \\
\text { Visit }\end{array}$ & $1071(98.7 \%)$ & $14(1.3 \%)$ & 1.047 & $2.5<0$ \\
\hline Diarrhea & 1st visit & $1202(97.6 \%)$ & $29(2.4 \%)$ & 4.328 & 0.042 \\
\hline & $\begin{array}{l}\text { 2nd } \\
\text { Visit }\end{array}$ & $1071(98.8 \%)$ & $13(1.2 \%)$ & & \\
\hline Fever & 1st visit & $1237(98.7 \%)$ & $16(1.3 \%)$ & 1096 & 0321 \\
\hline & $\begin{array}{l}\text { 2nd } \\
\text { Visit }\end{array}$ & $1075(99.2 \%)$ & $9(0.8 \%)$ & 1.070 & $0.3<1$ \\
\hline Malnutrition & 1st visit & $1078(89.8 \%)$ & $122(10.2 \%)$ & 56.712 & 0.000 \\
\hline & $\begin{array}{l}\text { 2nd } \\
\text { Visit }\end{array}$ & $1058(97.6 \%)$ & $26(2.4 \%)$ & 50.112 & 0.000 \\
\hline Anaemia & 1st visit & 1055 (86.5\%) & $164(13.5 \%)$ & 78462 & 0000 \\
\hline & $\begin{array}{l}\text { 2nd } \\
\text { Visit }\end{array}$ & $1042(96.9 \%)$ & $33(3.1 \%)$ & & \\
\hline Other Problem & 1st visit & $1070(92.1 \%)$ & $92(7.9 \%)$ & 41801 & 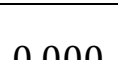 \\
\hline & $\begin{array}{l}\text { 2nd } \\
\text { Visit }\end{array}$ & 1035 (98.1\%) & $20(1.9 \%)$ & 41.001 & 0.000 \\
\hline
\end{tabular}

N.B: * Significant, ${ }^{* *}$ Highly Significant 
Table: 5: Quarter wise comparison IMNCI Implementation Report.

\begin{tabular}{|c|c|c|c|c|}
\hline Indices & $\begin{array}{l}\text { Age } \\
\text { Group }\end{array}$ & 1st \& 2nd Quarter & 2nd \& 3rd Quarter & 3rd \& 4th Quarter \\
\hline \multirow{2}{*}{$\begin{array}{l}\text { Referral } \\
\text { rate }\end{array}$} & $\begin{array}{l}0 \\
2 \text { month }\end{array}$ & 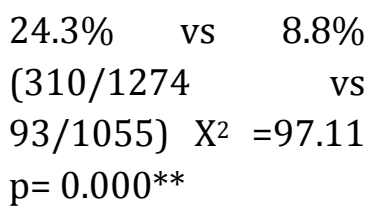 & $\begin{array}{l}8.8 \% \text { vs } 5.3 \% \\
(93 / 1055 \quad \text { vs } \\
58 / 1093) X^{2}=10.11 \\
p=0.001 *\end{array}$ & $\begin{array}{l}5.3 \% \text { vs } 7.4 \% \\
(58 / 1093 \\
110 / 1486) \\
X^{2}=4.54 p=0.033^{*}\end{array}$ \\
\hline & $\begin{array}{l}2 \text { month } \\
\text { - 5years }\end{array}$ & $\begin{array}{l}9.8 \% \text { vs } 5.3 \% \\
(159 / 1618 \quad \text { vs } \\
78 / 1472) X^{2}=22.32 \\
p=0.000^{* *}\end{array}$ & $\begin{array}{lll}5.3 \% \quad \text { vs } & 4.8 \% \\
78 / 1472 & & \text { vs } \\
79 / 1636) & X^{2}=0.36 \\
p=0.550 & \end{array}$ & $\begin{array}{l}4.8 \% \text { vs } \quad 7.4 \% \\
(79 / 1636 \quad \text { vs } \\
144 / 1933) X^{2}=10.02 \\
p=0.002 *\end{array}$ \\
\hline $\begin{array}{l}\text { Home } \\
\text { Visit } \\
\text { Within } 24 \\
\text { Hours }\end{array}$ & & $\begin{array}{l}49.8 \% \text { vs } 48.3 \% \\
(1355 / 2721 \\
1448 / 2996) \\
X^{2}=1.28 p=0.257\end{array}$ & $\begin{array}{lr}48.3 \% \text { vs } & 60.1 \% \\
(1448 / 2996 & \text { vs } \\
1534 / 2551) & \\
X^{2}=77.12 p=0.000^{* *}\end{array}$ & $\begin{array}{lr}60.1 \% \text { vs } & 74.1 \% \\
(1534 / 2551 & \text { vs } \\
2387 / 3221) & \\
X^{2}=10.02 p=0.002 *\end{array}$ \\
\hline $\begin{array}{l}3 \text { PNC visit } \\
\text { within } \\
\text { 10days }\end{array}$ & & $\begin{array}{lr}78.4 \% \text { vs } & 51.2 \% \\
(2134 / 2721 & \text { vs } \\
1534 / 2996) & \\
X^{2}=458.3 p=0.000^{* *}\end{array}$ & $\begin{array}{lr}51.2 \% \quad \text { vs } & 58.1 \% \\
(1534 / 2996 & \text { vs } \\
1483 / 2551) & \\
X^{2}=26.39 p=0.000^{* *}\end{array}$ & $\begin{array}{l}58.1 \% \text { vs } \\
(1483 / 2551 \\
2146 / 3221) \\
X^{2}=44.0 p=0.000^{* *}\end{array}$ \\
\hline
\end{tabular}

